\title{
Study on the Development of County Tourism
}

\author{
Take Yinan County for example
}

\author{
Aishui Yu \\ Business Academy of Linyi University \\ Linyi, Shandong, China, 276005
}

\begin{abstract}
As the basic regional unit of the administrative divisions - county, its tourism development will affect the overall situation of tourism in our country. So the study on the development of county tourism plays a significant role in promoting the development of county tourism. Recent years have witnessed a rapid development of tourism in Jinan County, which has been a typical example of the development of county tourism. By an intensive study on its development status, characteristics, main problems, strategies, etc., some enlightenment for guiding the development of county tourism is finally got.
\end{abstract}

Keywords-county; tourism; Jinan; enlightenment

\section{INTRODUCTION}

The development of tourism today is like a raging fire and there is no doubt that the development of county tourism has attracted much attention. Shandong Province launched a rural tourism plan within the scope of the province in 2013, which injected a strong driving force for the development of county tourism. Later on, Linyi City made an extensive investigation on the development of county tourism, finding that Yinan County has enjoyed a rapid development of tourism in recent years and has successfully made its own way, growing from small to large and from weak to strong. On the basis of the indepth research, it put forward "Yinan Mode'. Its successful experience attracted the attention of Shandong Province, as well as the whole nation, and it also offered lots of experience, worth learning, to the tourism development of less developed counties.

\section{ORganizATION OF THE TEXT}

\section{A. Tourism development status}

Located in the hinterland of Yimeng mountain area with Jinghu Expressway, Ridong Expressway and Jiaoxin Railway within the border, and an area of 1,719.28 square kilometers, Yinan County has a long history and a glorious revolutionary tradition. It used to be called Yangdu, which is the hometown of the famous god-man of wisdom, Zhuge Liang, and Yimeng 'Red Sisters-in-law', it is also the National-level Cultural Relics Preservation Unit, where there are North Village Carvings Stone Tombs from Han Dynasty. In recent years, Yinan County has established the tourism development strategy of "Perform ecological drama under culture brand" according to the general idea of "Cultivate broad environment, construct big industry and develop macro-tourism" and the goal of creating a strong county of tourism. It works hard to create five special tourism brands, respectively, the cultural town, the hometown of Yimeng sisters-in-law, the town of bamboo spring and old villages, the drift town of Shandong and the spring town. Some tourism projects, such as Zhuge Liang Cultural Tourism Zone, Yimeng Movie and Television Base, Bamboo Spring Tourism Zone, Zhisheng Tangquan, etc. have gradually marched into the market and the tourism has turned out to be a good trend of healthy, well-organized, rapid and sustainable development. So far, over 20 tourist scenic spots, one landscape tourist town with national characteristics and two provincial tourism strong towns have been constructed, which has initially formed an unique brand of tourism, that is, "The Hometown of God-man of Wisdom, the Hometown of Red Sisters-in-law, the Spring Town and the Leisure Resort".

Table 1: Historical statistics of tourism development of Yinnan County

\begin{tabular}{|c|c|c|c|c|}
\hline Year & $\begin{array}{c}\text { National } \\
\text { Grade A } \\
\text { scenic } \\
\text { spots }\end{array}$ & $\begin{array}{c}\text { No. of the } \\
\text { tourists } \\
\text { (ten } \\
\text { thousand) }\end{array}$ & $\begin{array}{c}\text { Tourism } \\
\text { revenues(1 } \\
\text { yuan) }\end{array}$ & $\begin{array}{c}\text { Year-on-year } \\
\text { growth rate of } \\
\text { tourism } \\
\text { revenues }(\%)\end{array}$ \\
\hline 2005 & 10 & 45 & 2.15 & $72 \%$ \\
\hline 2006 & 12 & 53 & 2.49 & $15.8 \%$ \\
\hline 2007 & 12 & 70 & 3.5 & $41 \%$ \\
\hline 2008 & 12 & 91 & 4.55 & $30 \%$ \\
\hline 2009 & 13 & 120 & 6 & $31.8 \%$ \\
\hline 2010 & 17 & 396 & 19.8 & $230 \%$ \\
\hline 2011 & 19 & 598 & 29.9 & $52.6 \%$ \\
\hline 2012 & 22 & 849 & 42.3 & $44.3 \%$ \\
\hline
\end{tabular}

\section{B. Development characteristics}

\section{1) Rapid development and increasing tourism income}

With the rapid development of scenic spots, such as Wen River Drift, Bamboo Spring Village etc., the number of tourists gradually increased and reached 8.49 million in 2012, the tourism income was over 4.23 billion yuan. With the continuous improvement of the external transport facilities and 
the exploration of new scenic spots, the tourist market is expanding and gradually sharing part of the tourism market with the brands of scenic spots, such as the underground caves in Mengshan and Yishui counties, etc.

2) Show the features of resources and excavate culture connotation

Yinan County is rich in tourism resources, especially in 'Red, green, old and spring" resources. The red culture is formed in the Anti-Japanese War and the Liberation War; the green culture relies on the natural ecological environment with three rivers and six shores and landscape dependency; the old culture takes Zhuge Liang and tombs of Han Dynasty as representatives and the spring culture is rich in spring resources and bamboo spring villages. While digging deep into the cultural resources, the county actively implements the strategy of developing the county through culture and tourism.

3) The market location is superior and the development prospect is bright

Seeing from the provincial range, Yinan County is located with rapidly growing-up peninsula urban agglomeration in the east and vast inland hinterland in the west, its special transferring location makes a nice prospect of the development of Yinan tourist areas. Seeing from the domestic market, located in the cohesion of Beijing-Tianjin-Tangshan metropolitan area and the urban agglomeration on Yangtze River Delta, Yinan's beautiful rural scenery and countryside leisure will always be the leisure destination of urban citizens. In addition, seeing from the international market, most of the overseas visitors will land on Shangdong Peninsula and pay a visit to the profound cultural background of China and then go to Quhu, Taian and inland through Yinan County and surrounding areas. Yinan attracts foreign visitors by profound cultural background (Tombs with Stone Carvings from Han Dynasty, red amorous feelings, etc.), unique folk customs and the beautiful rural scenery.

4) The whole awareness is low and the tourism marketing remains to be strengthened

The tourism development of Yinan County is much too quickly and it takes time to enhance the market popularity. Compared with the surrounding counties, such as Yishui, Mengyin, etc., the popularity of the three types of tourism products - cultural experience, natural ecology and leisure holidays, is a little low and the construction of scenic spots is relative lag. Although it has set up the tourism image of "The hometown of Zhuge Liang and Red Sisters-in-law", less cultural relics of Zhuge Liang and Red Sisters-in-law culture in the scenic spots and other factors affected the recognition of the tourism image. However, it spends less on tourism marketing and fails to share the tourist market with Yishui County, etc. and the regional tourism cooperation needs to be strengthened.

5) Develop by leaps and bounds to form tourism product advantages

Yinan has built a group of leisure products, taking two springs and a base as the core, and its position and characteristics conform to the development trend of modern leisure tourism. The bamboo spring village tourist resort is the first system-developed Grade 4A scenic spot with old villages in Shandong Province and it has become one of the first series of "Leisure tourism" demonstration spots. Zhisheng Tangquan has been built to be the fourth generation of hot spring tourist resort and Grade 4A scenic spot with the largest scale in Jiangbei and domestic first-class facilities. Zhemeng Red Film and Television Base has finished the shooting of more than 20 television works, such as the large TV series "Zhemeng" and the film "Six sisters of Zhemeng", the brand effect has been preliminarily formed.

\section{Major problems}

1) The tourism elements aren't well developed and the modern industry system hasn't taken shape

Six tourism elements aren't well developed and the construction isn't reasonable. In the developing process, much attention is paid to spot construction of scenic spots while other elements are ignored, especially shopping and amusement. Most of the tourist shopping products are local specialties, which don't agree with the majority, let alone tourist souvenirs, lacking of or even without characteristics. With the constant extension of tourism industry chain, many scenic spots have evolved from sightseeing to vacation. The tourists' consumption is high and they will stay for a long time and are more interested in tourism products about culture etc. Yinan County should improve its own system of tourism according to this new trend of tourism development.

2) Tourism attraction needs improvement and the environmental construction still needs enhancement

The tourism destination includes three aspects: they are attraction element, service element and environment element. Only when the three aspects improve together can the effect of tourism linkage be made full use of to achieve the transformation from resource disadvantages to economical advantages. At present, Yinan County is lack of the overall building of tourism destination and the comprehensive attraction of tourism areas isn' t strong, which is the block of the tourism development. In today's transformation from sightseeing tourism to recreational tourism, people mainly travel to relax and have fun. Their attention to the scenic spots are reducing while their requirements on the opening degree of the tourist destination, transportation, safety, coziness, health, service, management etc. are stricter and stricter, all these are weak points of Yinan tourist destination construction.

3) The depth of comprehensive development isn't enough and its economical driving force isn't strong enough

Tourism is a highly comprehensive industry and the current Yinan tourism only stays on the sightseeing level, the tourism chain is short and the economical driving force isn't strong enough, reflecting that the rate of ticket income is much too large while the development of leisure shopping and tourist souvenirs is very slow. In the next step, Yinan should intensify the development of folk arts and try hard to develop tourist goods and souvenirs with strong local characteristics and regional customs and deep process the agricultural and sideline 
products to update the development, processing and selling links of tourist goods with comprehensive package. Thus to accelerate the fusion development of tourism along with urban $\&$ rural construction, sightseeing agriculture, sports, etc. then to lead the rapid development of county economy.

\section{4) Lacking of investment and weak marketing}

Lacking of investment is one of the main blocks of the county's tourism development. In today's rapid development of tourism, relying on the government's limited funds, it is difficult to meet the enormous market demands, which will lead to weak infrastructure and the implementing of many plans. Moreover, the marketing is weak and the county hasn't formed a thick atmosphere of "big tourism development", the tourism publicity funding is inadequate, the marketing way is single and many tourist resources are still in an idle state. In the next step, when expanding the marketing campaign in the mainstream media, it should also strengthen the construction of sign system on both sides of the road to gradually improve the popularity and the accessibility degree of scenic spots.

5) Weak tourist infrastructure is bad for the development of large tourism

When developing tourism, the construction of infrastructure should be especially paid attention to. The infrastructure construction of Jinnan County can' $t$ reach the demand of developing large tourism and it mainly manifests in that the condition of the path to the scenic spot and loop roads between scenic spots is poor and the facilities for the roads, sign system, water supply, power supply, communication, washrooms, rubbish and wastewater treatment of the main scenic spots remain to be perfected; the greening along the tourism road and the landscape construction need improving; the county is lack of tourist service center, the county tourism information service system needs to be improved and the function of offering publicity materials of tourism, tourist inquiry, tourist activities and tourist complaints, etc. is a little weak; the environment construction of tourist villages and towns needs to be enhanced and the food, clothing, shelter, washroom, parking, greening and environmental health problems should be mainly solved.

\section{Development Strategies}

\section{1) Master the chance to quicken talents training}

Now Shandong Province has entered the golden period of developing rural tourism, the provincial government should put more efforts on the development of rural tourism in the current and the future period of time to make Shandong a tourism strong province. Jinan County should grasp this historic opportunity to make good plans and promote the construction of tourism strong towns and tourism special villages when making it a tourism strong county. The sustainable development of the tourism depends largely on the cultivation of tourism talents training and the optimization of team. Administers of the scenic spot should pay attention to the pre-job training of staff and check the internal literacy assessment of the staff at a regular time, the requirements shouldn't be lowered because of the large turnover rate of staff.
Add the introduction of scientific and cultural knowledge to make tourists gain knowledge when advertising the scenic spots. Yinan is located in the hinterland of Yimeng old areas with a deep atmosphere of red culture and it educates tourists to recall bitterness in the old society, which caters for the current trend of thrift. It is close to the birthplace of Dongyi culture to let tourists appreciate different old culture.

2) Transform the government's functions and promote the mode innovation

The government plays a significant role in the tourism development, so it is important to enhance the coordination function of the government and establish management system in accordance with the market economy. The government staff should make themselves examples, take the public interest in the first place, regulate their own behaviors according to the rules and regulations, actively accept the supervision of the public and public the government work files to improve transparency and do practical things foe the mass. At the same time, it has to strengthen the team construction to serve people with probity and efficiency and actively introduce high level talented managers to lead the healthy tourism development of Yinan.

Accelerate institutional innovation, especially the financing system innovation and actively explore the business of management right pledge and ticket income right pledge of scenic spots to support those scenic spots with a good market prospect and stable cash flow to explore the pilot of asset securitization. In the aspect of management system, it should vigorously develop tourism specialized cooperatives and support different cooperation modes, such as the cooperative, company and farmers, the scenic spot and farmers, the company and farmers, the association and farmers, etc.

3) Strengthen market development and promote brand construction

The tourism of Yinan County started a little late and its market recognition is a little low. The current work is mainly to mold the destination brand of "Han characteristics and wise Yinan" to improve the brand recognition and market penetration so as to promote the transformation of Yinan tourism from capital export to brand export. When doing the tourist brand well, it should also strengthen the brand construction of tourist enterprises to vigorously develop comprehensive tourist enterprise group, optimize the management environment and actively introduce famous tourist enterprises at home and abroad. Government departments should scientifically plan the layout of resource exploring to avoid vicious competition, caused by over dense homologous aggregation of resources, enhance market supervision, strike hard business price wars and rationally guide the price while ensuring the tourism quality.

4) Integrate the resources and optimize the development pattern

The optimization of tourist room can improve the comprehensive competitiveness of the county tourism. It should continuously enhance the city center' $s$ functions of tourism \& leisure and comprehensive service from the space 
according to the principle of " homogeneous repulsion, heterogeneous phase" . Take those existing products as leaders, such as the Bamboo Spring, Yimeng Red Film and Television Base, Zhisheng Tangquan, etc to promote the construction of weak scenic spots, especially the development of Caimeng, Yihe River ecological leisure zone should be accelerated. When developing the scenic spots, the coordinated development of economic benefit, social benefit and ecological benefit should be paid attention to. We shouldn' $t$ only focus on the economical effect of resources while ignoring the ecological benefits and long-term interest. At the same time, enhance product integration and optimize the space layout to improve the comprehensive competitiveness.

5) Insist on coordinate development and advance the construction of global tourism system

Insist on coordinate development and optimize the industrial structure, upgrade the production grade, promote the transformation and upgrading of tourism industry and cross domain development, construct the panorama of Yinan development pattern, achieve full coverage of space tourism and industry and meet the composite needs of tourists. Taking building the national tourism standardized demonstration county as the starting point to promote the tourism industry cluster, refined products, management planning, market marketing and family-like services, to continuously develop creative tourism products and create competitive tourism products, and promote coordinate development of tourism with other industries.

\section{CONCLUSION}

Try hard to accelerate the integration of regional resources and the integration of tourism with other industries, the realize global coverage of tourism space, integrate all the elements of tourism development, dress up the urban with rural tourism as the center, develop industry with tourism as the center and display culture with tourism as the center. In the agricultural area, establish sightseeing agricultural parks, give the tourism functions and enrich the connotation of agricultural leisure sightseeing; in ecological area, depending on the comprehensive improvement of the urban and rural environment to beautify the garden and color the project; in the cultural and sports area, treat culture as the soul of tourism and show the rich history and culture of Yinan. In addition, plan the government and the enterprise as a whole, continue to adhere to the government leading direction, strengthen the industrial policy, guide enterprise investment and lengthen the tourism industrial chain through scientific polices, and protrude tourism's leading position in the county economy.

The development of county tourism should improve the quality of tourism development from the aspects of resource, product, space, management, etc. and optimize the county destination system. For the resources, pay an active attention to the exploring and development of the own resources, form the own characteristics and try to avoid coincidence with surrounding scenic spots. For products, basing on the resource evaluation to create competitive products, centered on leisure tourism and culture experience, and enhance the resort function. For the space, continue to improve the county as the center, optimize the space layout and bring convenient journeys for tourists. For the market, make efforts to create competitive products, enhance marketing, widen the market range and upgrade the market level, enhance market supervision and promote the coordinated development of tourism related industries.

\section{REFERENCES}

[1] The government of Yinan County, Statistical Yearbook of Yinan County (2012).

[2] Tourism Information Network of Yinan County, http://276300.114133.com/user/16264/. 